Women in Lebanon 
This page intentionally left blank 


\section{Women in Lebanon}

Living with Christianity, Islam, and Multiculturalism

Marie-Claude Thomas 


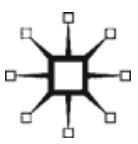

WOMEN IN LEBANON

Copyright (C) Marie-Claude Thomas 2013.

Softcover reprint of the hardcover 1st edition 2013 978-1-137-28198-2

All rights reserved.

First published in 2013 by

PALGRAVE MACMILLAN ${ }^{\circledR}$

in the United States—a division of St. Martin's Press LLC, 175 Fifth Avenue, New York, NY 10010.

Where this book is distributed in the UK, Europe and the rest of the World, this is by Palgrave Macmillan, a division of Macmillan Publishers Limited, registered in England, company number 785998, of Houndmills, Basingstoke, Hampshire RG21 6XS.

Palgrave Macmillan is the global academic imprint of the above companies and has companies and representatives throughout the world.

Palgrave ${ }^{\circledR}$ and Macmillan ${ }^{\circledR}$ are registered trademarks in the United States, the United Kingdom, Europe and other countries.

ISBN 978-1-349-44842-5 ISBN 978-1-137-28199-9 (eBook)

DOI $10.1057 / 9781137281999$

Library of Congress Cataloging-in-Publication Data

Thomas, Marie-Claude.

Women in Lebanon : living with Christianity, Islam, and multiculturalism / Marie-Claude Thomas.

p. $\mathrm{cm}$.

1. Women-Lebanon. 2. Muslim women-Lebanon.

3. Christianity and other religions-Islam. 4. Islam-Relations-Islam.

5. Multiculturalism-Lebanon. I. Title.

HQ1728.T46 2013

$305.4095692-\mathrm{dc} 23$

2012036659

A catalogue record of the book is available from the British Library.

Design by Integra Software Services

First edition: January 2013

10987654321 


\section{Contents}

List of Figures vii

Acknowledgments $\quad$ ix

Introduction 1

Part I Saghbine, a Christian Village: Women, Religion, and Society

1 Geography and Religious Spaces 15

2 Childhood and Adolescence of Young Girls 31

3 Marriages and the Condition of Married Women 43

4 Adulthood, Married Life, and Women's Work Outside the

Interview-Individual Perspectives: Christian Discourse 75

\section{Part II Muslim Lebanese Women and an Islamic} Modernity

5 Islam in Lebanon: An Overview 83

6 Struggle in Modern Islam 103

7 Veiling and Divergent Feminist Voices 117

8 Personal Status Laws in Islam: Sheikh Muhammad Hussein Fadlallah's New Tafsir (Exegesis)

Interview-Individual and Communal Perspectives: Muslim

Discourse

\section{Part III Transformation within a Multicultural Lebanon}

9 Modernity, Multiculturalism, and Lebanese Women

10 Christian-Muslim Relations, Women, and Religion 
11 Lebanese Women in All Their Diversity: Convergence and Divergence

12 En Route toward a More Inclusive Civil Society

Conclusion

Notes

Bibliography

Index 


\section{List of Figures}

1.1 After-church gathering

30

3.1 Wedding

60

5.1 Lebanon map 
This page intentionally left blank 


\section{Acknowledgments}

The book grew out of my sense of the prominent participation of women in projects of modernity. I am grateful to my late advisors at the University of Paris 1-Pierre Thillet and Yoakim Moubarac-who supported me when I suggested the theme of my dissertation on the status of women in my hometown in Lebanon. My thanks go to Margaret Kamitsuka, who helped me to expand the basis of my dissertation for this project and encouraged me in its pursuit. My work has greatly benefitted from conversations with her, and her insights and comments on parts of the manuscript were particularly valuable. Her friendship and generosity sustained me throughout my endeavor. My thanks go to my daughter Joelle Thomas, who has contributed to the project in subtle and practical ways. Her presence during a trip to Lebanon pushed me to think more clearly and to articulate why the change taking place in Lebanon matters for the future perspective of Lebanese women. I particularly thank her for her suggestions and the editorial help throughout this project. She has and continues to be an inspiration to me. I would also like to thank Michael Fisher and the reviewers who were generous enough to read parts of the manuscript and bring insightful comments-Yvonne Haddad for her constructive criticism and Guy Imhoff for his positive remarks. My thanks go to my former students at Oberlin College and especially to Rebecca Newman for her editorial help. I also offer my gratitude to the women and men I interviewed for bigheartedly sharing their perspectives and time. We used the Arabic language in our conversation; I then translated all interviews into English. For privacy reasons, however, I have not disclosed their real names and instead used given ones. Finally, I wish to thank the editorial staff at Palgrave Macmillan in preparing the manuscript for publication.

A different kind of thanks go to my mother, Georgette Gemayel Khoury, whose resilience and devotion in helping others have inspired much of what 
I said; my brothers, Paul and Noel Khoury, who were always available to answer my quests and graciously provided me with documents I needed from Lebanon; my son, James Thomas, for his technical aid in preparing the photos and cover art displayed; and, lastly, my husband, Norman Thomas, whose energy has kept me and this project afloat. 